\title{
A Logistics Barometer for South Africa: Towards sustainable freight mobility
}

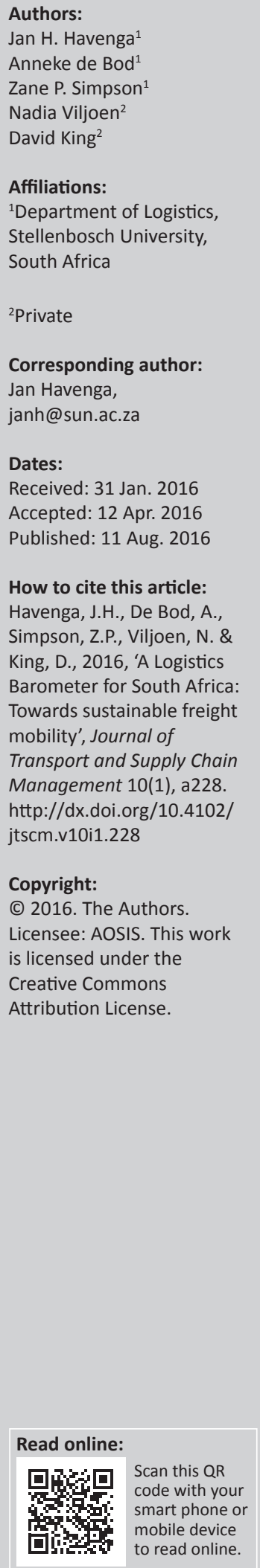

Background: South Africa has a disproportionately high freight transport demand owing to industrial development far from ports, low domestic beneficiation and improper modal use. Historical freight transport policy supported primary economic development, failing to preempt the changing economic structure and the resulting freight transport needs, resulting in excessive transport costs and externalities.

Objectives: To share the macroeconomic freight transport challenges revealed by South Africa's Logistics Barometer, and to identify key interventions to address these.

Method: Freight flows are modelled by disaggregating the national input-output model into 83 commodity groupings and 372 geographical areas, culminating in a 30-year forecast at 5 -year intervals for three scenarios, followed by distance-decay gravity modelling to determine freight flows. Logistics costs are calculated by relating these flows to the costs of fulfilling associated logistic functions.

Results: Long-distance transport remains the largest general freight typology and is, due to inefficient macro logistics design, extremely costly, both in terms of intrinsic and extrinsic costs.

Conclusion: South Africa's freight task will grow 2.5-fold by 2043. Logistics and externality costs are already untenable at current levels. The development of domestic intermodal solutions will support the drive towards sustainable freight mobility.

\section{Introduction}

South Africa's contribution to global surface transport intensity, measured in tonne-kilometres (tonne-km), is more than double its contribution to global gross domestic product (GDP) (Table 1). South Africa's contribution to global trade is ever more disproportionate, handling $1.3 \%$ of the world's liquid bulk trade, $1.7 \%$ of containers and $5.1 \%$ of dry bulk. South Africa is therefore a transport-hungry country, rendering logistics a strategic resource that demands deliberate macroeconomic attention. With freight logistics costs totalling 11.1\% of GDP in 2013, this strategic resource is not managed efficiently (Stellenbosch University 2015; World Bank 2015).

The University of Stellenbosch (South Africa) launched its inaugural Logistics Barometer in 2015, building on the national State of Logistics survey (The Council for Scientific and Industrial Research [CSIR], Imperial Logistics \& Stellenbosch University 2013), to contribute to a wider macroeconomic understanding of South Africa's freight logistics system through an in-depth quantitative perspective. This research forms part of the research team's involvement in the global knowledge network on sustainable logistics (sponsored by the World Bank, refer World Bank 2012) to enhance country-specific measurement of logistics costs trends and to facilitate the macroeconomic application thereof.

The purpose of this paper is to share the results of South Africa's Logistics Barometer and identify key steps to address identified challenges. The literature survey provides international context to the challenges experienced globally in rail freight; the research methodology outlines the methodology for South Africa's freight logistics costs and flow models; the research output shares the results and identifies the country's freight logistics challenges; and the conclusion summarises the salient points of the research and the next steps.

\section{Literature survey}

The industrialisation of break-bulk shipping via the introduction of the intermodal shipping container, and the concomitant cost reduction impact on international trade, was a key facilitator of production offshoring and globalisation (Tomlinson 2009). Physical distance and transport cost 
became obsolete in comparison with the progressive rise of added value on a product (Verny 2007).

Containerisation allowed the standardisation of break-bulk goods close to the point of manufacturing, facilitating loading and transport. In the early 1960s, in addition to the rapid standardisation of container sizes, agreements were also reached on container strength to allow container stacking and expand transportation from ship and truck to train (Tomlinson 2009). The changing economic structure to justin-time manufacturing, coupled with frequent small deliveries, favoured road transport in the absence of appropriate rail solutions.

The reduction in rail's market share is attributed to this divergence between rail services and customer requirements, as well as insufficient technical development (Ghaderi, Fei \& Cahoon 2015; Nelldal \& Troche 2000). In Australia, rail's non-bulk tonne-km market share deteriorated from $43 \%$ to $16 \%$ between 1970/1971 and 2009/2010 (Australian Government 2013). In the European Union, rail share of inland tonne-km declined from $31 \%$ to $15 \%$ between 1970 and 1995, while the transport task almost tripled in size (Nelldal \& Troche 2000), subsequently stabilising at around $18 \%$ in this millennium (Eurostat 2014). The over-shifting to road transport of the non-bulk task has led to supply chain bottlenecks and inefficient use of infrastructure, that is, the overuse of roads and under-utilisation of rail (Ghaderi et al. 2015).

This is in sharp contrast to rail tonne-miles in the United States which has steadily outperformed that of road over the past two decades (Figure 1). Rail's performance in the United States

TABLE 1: Key transport and trade indicators - South Africa versus the global economy (Stellenbosch University, 2015).

\begin{tabular}{lc}
\hline Indicator & Percentage of global economy \\
\hline GDP & 0.4 \\
Tonne-km & 1.0 \\
Liquid bulk trade & 1.3 \\
Container trade & 1.7 \\
Dry bulk trade & 5.1 \\
\hline
\end{tabular}

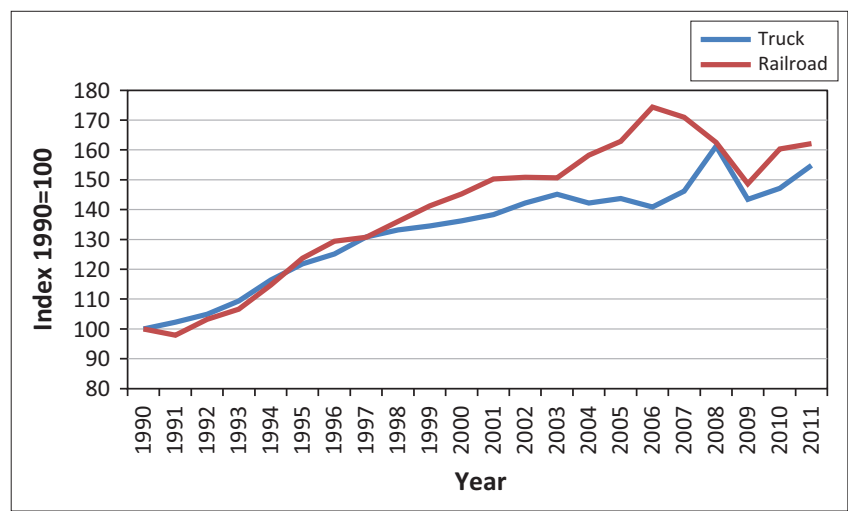

Source: United States Department of Transportation, 2015, Table 1-50 - U.S. Ton-Miles of Freight (BTS Special Tabulation), National Transportation Statistics, viewed 26 Novembe 2015, from http://www.rita.dot.gov/bts/sites/rita.dot.gov.bts/files/publications/national_ transportation_statistics/index.html

FIGURE 1: United States truck and railroad tonne-miles. is attributed to the commercial freedom brought about by deregulation, allowing major network and employee rationalisation, facilitating significant investments and subsequent efficiency gains (Association of American Railroads 2015a; Havenga et al. 2013). This enabled the US railroads to take advantage of the heavy-haul potential offered by rapid containerisation.

The US rail renaissance of the 1990s and the first decade of the 20th century was fuelled by international intermodal traffic, such that between 2003 and 2007 intermodal (i.e. seeing container movements by rail as a commodity) was the largest rail commodity by revenue (coal trumped again during the recession, but intermodal reached its pre-recession levels by 2012, the fastest of any rail commodity). In 2014, intermodal was again the largest single source of US freight rail revenue. The growth is, in part, owing to large investments in intermodal terminals, tracks and other critical infrastructure to make intermodal reliable and effective (Association of American Railroads 2015b). Railroads invest five times more than the average US manufacturer (Association of American Railroads 2013). The 2010s have been characterised by a second wave of growth in the United States, attributable to domestic intermodal transport (Hatch 2014). The growth in the US rail intermodal traffic is depicted in Figure 2.

Woodburn (2012) reports an upward trend for British rail freight market share from $8.2 \%$ in 1995 to $11.3 \%$ in 2010 . Domestic intermodal increased by $62 \%$ in absolute volume, becoming the largest commodity for which statistics are published. Haucap and Pagel (2014) report that the success of new market entrants in Germany has been mainly based on their strengths in delivering intermodal transport and block train traffic.

According to Woodburn (2012), the domestic intermodal potential in Britain can only be fully addressed through explicit measures by policy makers to promote domestic intermodal traffic, and through targeted investment in intermodal interchanges and terminals. Ghaderi et al. (2015) confirm that the development of intermodal freight is regarded as a key mechanism for rail achieving a greater share of the Australian freight market.

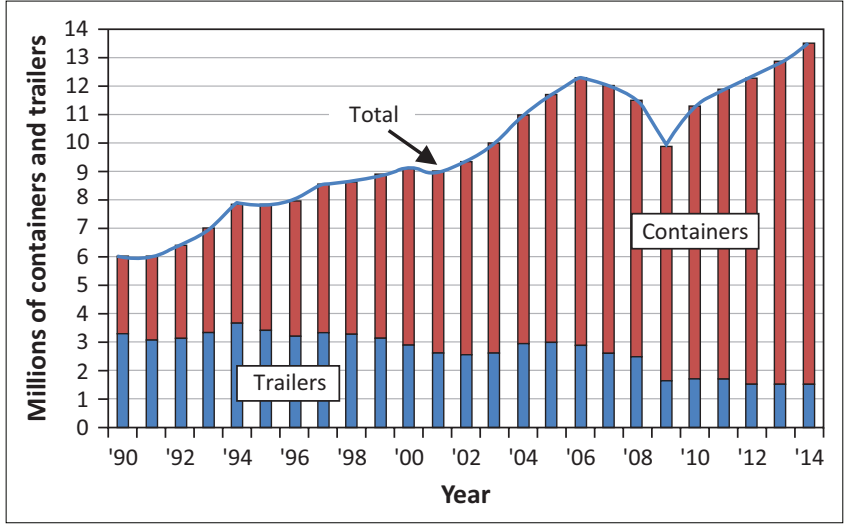

Source: Association of American Railroads, 2015b, Rail Intermodal keeps America moving viewed 10 September 2015, from https://www.aar.org/BackgroundPapers/Rail\%20 Intermodal.pdf

FIGURE 2: United States rail intermodal traffic (millions of containers and trailers). 
These interventions focus on the optimisation of transport supply. Verny (2007) refers to this as the relative uncoupling of transport demand and GDP and also urges for the absolute uncoupling of these two constructs. Absolute uncoupling takes place when transport demand itself is reduced through inter alia the spatial reorganisation of productive capacity (thereby reducing distances travelled).

In order to address these rail and, ultimately, transport industry challenges, reliable freight data and appropriate information sharing are essential to enable informed decisions on policy, planning and operations associated with freight transport (Browne, Woodburn \& Allen 2007; Ghaderi et al. 2015; Transportation Research Board 2011).

As a starting point, two fundamental macroeconomic measures are proposed for freight transport. Firstly, freight logistics costs as a percentage of GDP is a barometer of the relative national efficiency of freight movement - being a composite measure of total freight costs and produced as a percentage sensitive to overall economic growth. Secondly, rail's relative market share of overall freight tonne- $\mathrm{km}$ is a barometer of the shift towards more sustainable modes (Havenga 2010; Transportation Research Board 2011).

The research methodology enables inter alia the quantification of these two fundamental measures for the South African economy and facilitates further in-depth analysis to inform decision-makers.

\section{Research methodology}

The Logistics Barometer relies on South Africa's established research to quantify logistics costs and transport volumes, refined over the past two decades.

The Freight Demand Model (FDM) is a demand-side model, based on the national input-output table. The FDM estimates supply and demand of commodities in geographical areas and translates these parameters into modal share through gravity modelling for 83 commodities in 372 geographical areas, culminating in a 30 -year forecast at 5-year intervals for three scenarios. The methodology was developed by the authors in 1998 and Transnet has been sponsoring the actual execution of the methodology since 2006 (Havenga 2013; Transnet 2015). Results are calibrated with industry research and correlated with known freight flows.

The national freight flow model (NFFM) is a supply-side model which translates vehicle counts into pre-defined longdistance and rural road freight flows (Havenga \& Pienaar 2012). By combining the functionalities of the FDM with the NFFM, bi-directional commodity flows can be estimated for road freight flows and compared with actual rail shipments in order to determine modal market share.

The logistics cost model is a bottom-up aggregation of logistics-related costs for commodity-level tonnes produced and imported, comprising transport, storage and porthandling costs, management and administration costs, and inventory carrying costs (Havenga 2010). The model was recently expanded to include detailed externality costs per mode pertaining to accidents, congestion, emissions, noise, policing and land-use value (Havenga 2015).

To make the research more current, due to the lag in actual data availability, the researchers adapted the methodology in 2012 to produce an estimate of the previous calendar year's costs. In 2013 this was expanded to forecast the cost of logistics for the current year (Havenga \& Simpson 2012, 2013).

\section{Research output}

South Africa's logistics cost as a percentage of GDP in 2013 was $11.1 \%$ (Figure 3). This was higher than in developed countries, such as North America at 8.8\% and Europe at 9.2\%, but competitive when compared with other developing regions such as South America at $12.3 \%$ and Asia Pacific at $12.8 \%$ (2013 data) (Armstrong \& Associates Inc 2015). Expressing logistics costs as a percentage of transportable GDP paints a slightly starker picture, inching over the 50\% mark from 2012 onwards. (A comparison between logistics costs and transportable GDP has not yet been found for other countries. It would require a sectoral logistics costs view and requires either a deeper search or engagement with researchers from other countries to ensure comparable results. Also, the measurement of logistics costs on a micro [firm] level, as many studies do, ignores the fact that upstream purchase prices include logistics costs that are now hidden and that logistics costs disappear in the sales price as the product moves downstream in the value chain).

Between 2009 and the 2015 forecast, transport costs' contribution increased from $52 \%$ to $58 \%$ of freight logistics costs, while inventory carrying costs and warehousing costs reduced by 3 percentage points and 5 percentage points, respectively, and management and administration costs remained constant (Figure 4). The increase in transport costs' contribution to logistics costs is mainly attributable to the rising price of diesel (Figure 5). In this economic climate, it is commendable that logistics costs as percentage of GDP remained between $11 \%$ and $12 \%$ since post-recession 2009 .

Transport therefore remains the most significant component of logistics costs in South Africa. In 2013, 85\% of transport costs were attributable to road transport tariffs with rail tariffs contributing approximately $13 \%$ and pipeline tariffs $2 \%$. (Port and maritime costs are traditionally excluded from the calculation of the national cost of logistics, in keeping with international benchmarks.) Fuel remains the biggest contributor to road transport costs (Figure 6). The remarkable halving of the oil price between June 2014 and January 2015 suggested a respite in road transport input costs, but a mere 18 weeks later diesel prices had increased by $22 \%$ (Figure 5). Volatility seems to be the only constant in the fuel price going forward. Mitigating this risk requires a more in-depth understanding of the structure of the transport market. 


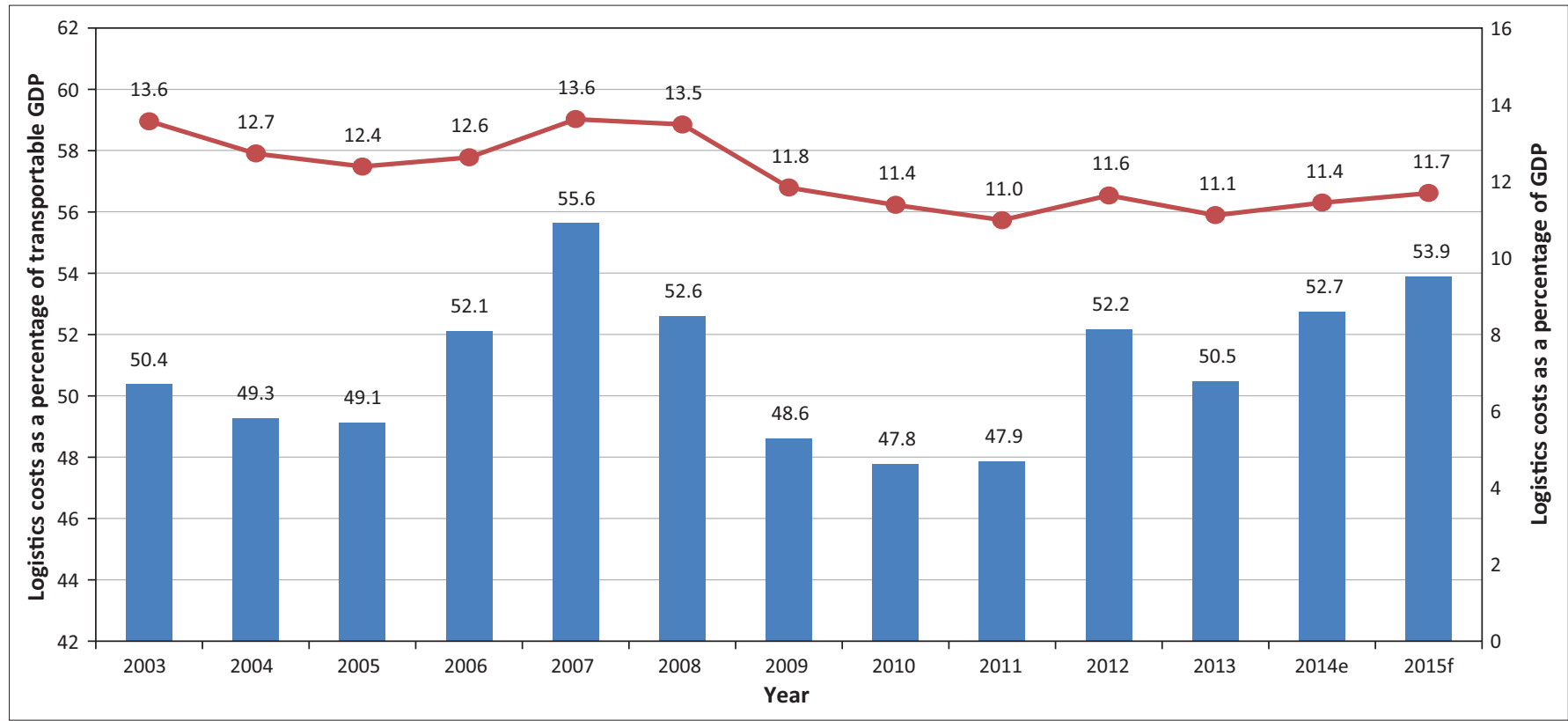

Source: To make the research more current, owing to the lag in actual data availability, the researchers adapted the methodology in 2012 to produce an estimate of the previous calendar year's costs (in this graph 2014e). In 2013, this was expanded to forecast the cost of logistics for the current year (in this graph 2015f) (Havenga \& Simpson 2013)

FIGURE 3: South Africa's logistics costs as percentage of total and transportable gross domestic product.

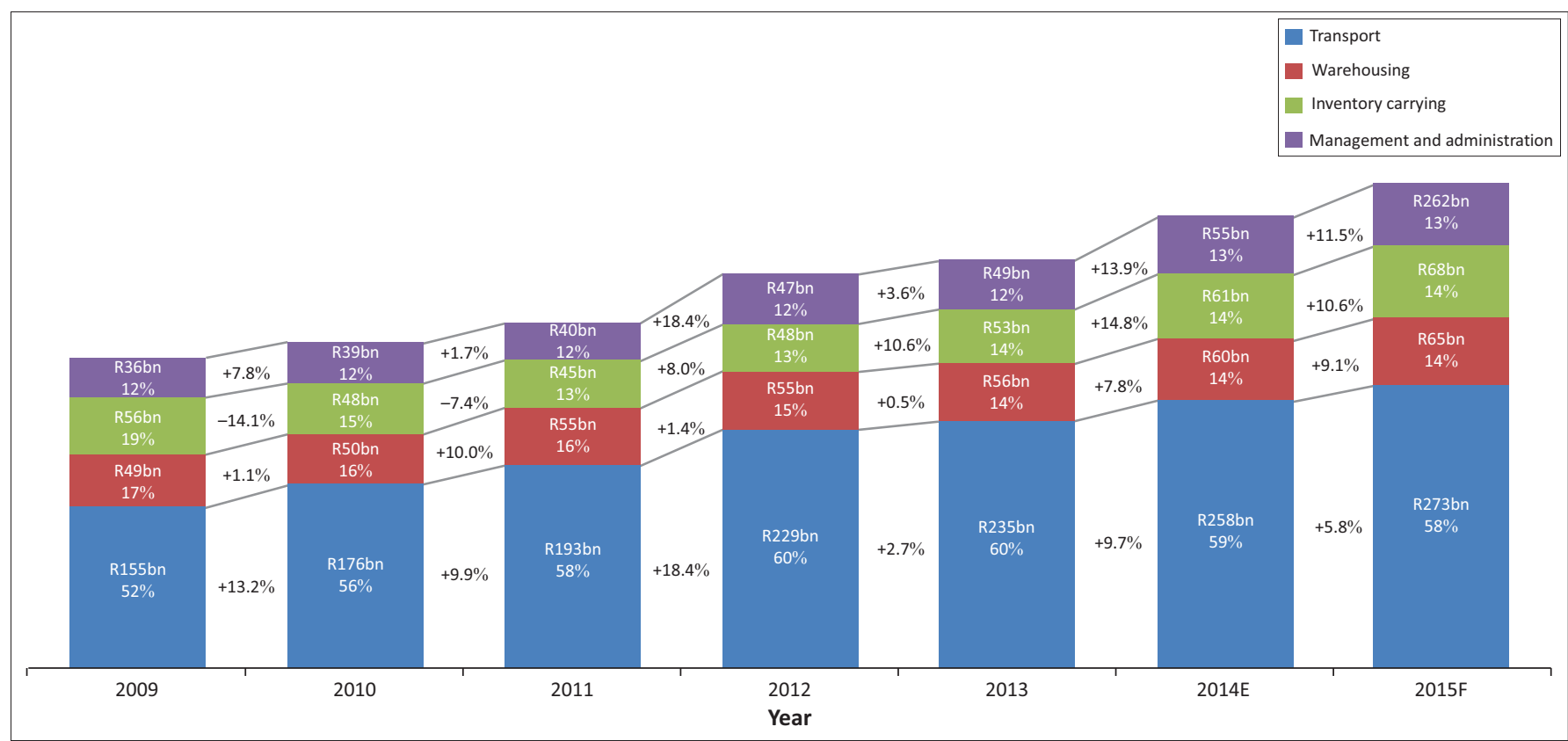

FIGURE 4: Logistics cost components tracked over time.

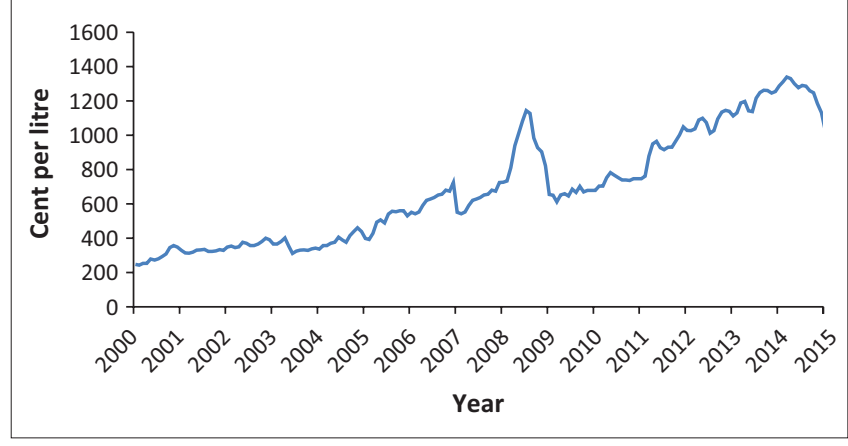

Source: SAPIA, 2015, Industry overview - Fuel prices archive, viewed 10 September 2015 from http://www.sapia.co.za/industry-overview/old_price.html

FIGURE 5: South Africa's diesel price trend.
In 2013, transportable GDP amounted to 782 million tonnes. Approximately $75 \%$ of this freight volume originated in the primary economy (agriculture and mining), with the remainder in the secondary (manufacturing) economy; yet, the latter contributed $54 \%$ of the transportable GDP value (Figure 7).

When looking at tonne-km (Figure 8 ), 28\% of freight transport activity is part of dedicated systems, namely the bulk export lines, pipelines, crude oil transfer systems and refineries and conveyor belts. (This freight is reported separately, as it is non-contestable, often closed systems that cannot viably move in any other way than the status quo.) The remaining 


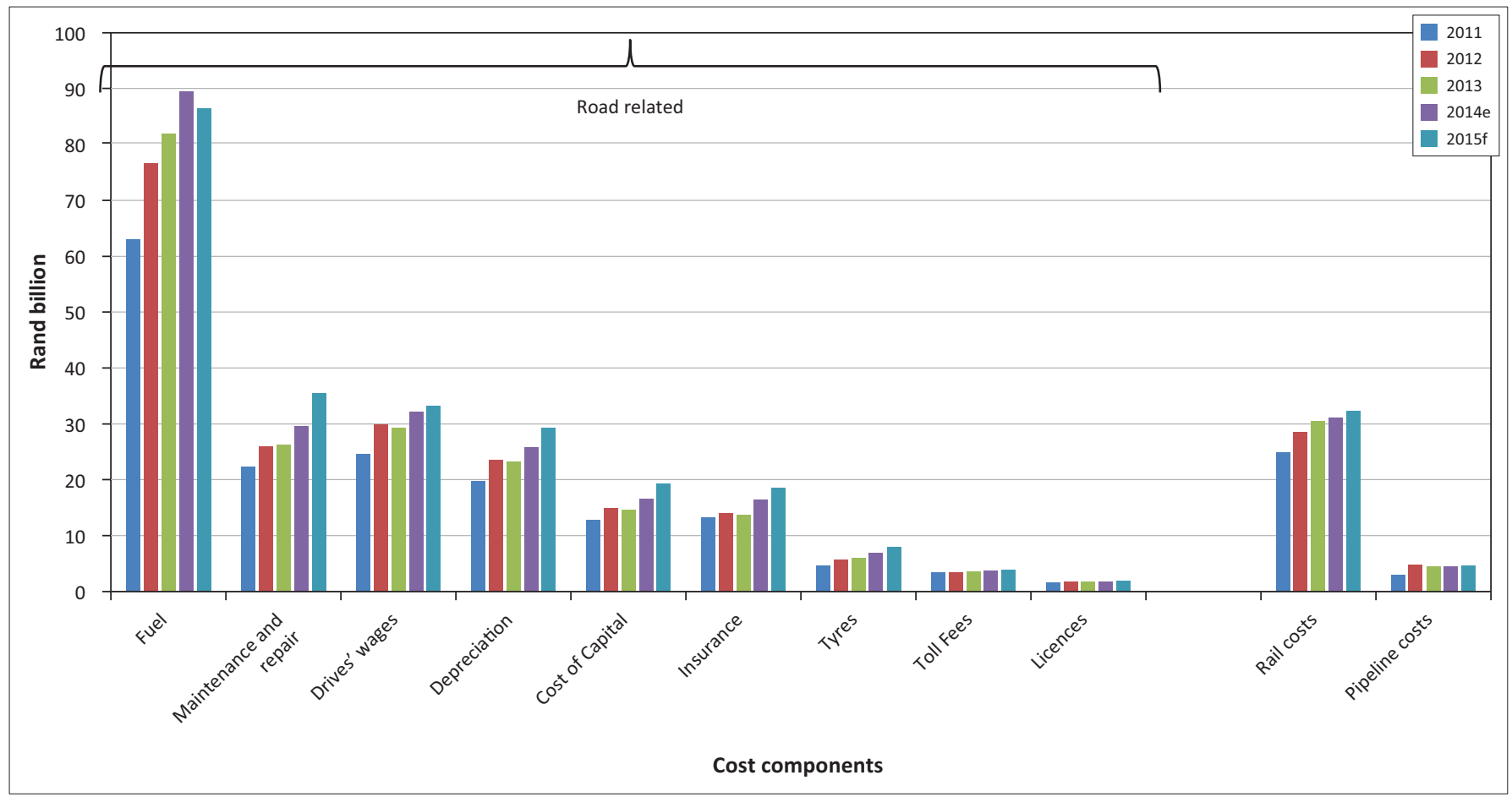

FIGURE 6: Transport cost components.

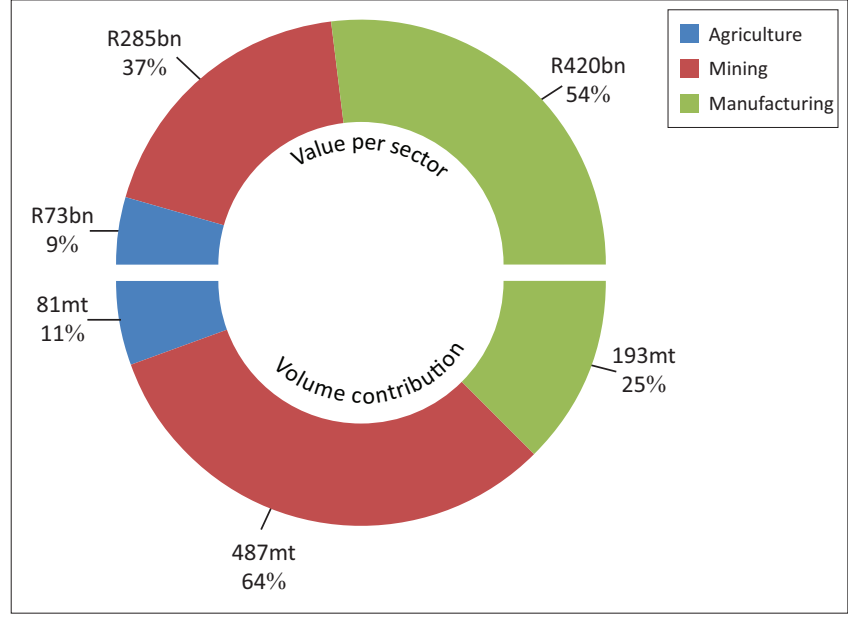

FIGURE 7: Volume and GDP value contribution of the transportable economy (2013).

$72 \%$ of freight transport activity on road (221 billion tonne-km) and rail general freight (39 billion tonne-km) use what can be called 'public' infrastructure. (This freight is often contestable between road operators and between road and rail, with many choices available to freight owners.) Of the 261 billion tonne-km using general freight systems, the $48 \%$ of freight on corridors is a main focus given the high volumes, long distances and low rail share (rail only has approximately $23 \%$ of the corridor freight tonne-km market).

The cost and market share structure of the freight flow market in South Africa is inter alia a result of policy and investment decisions of the past century. Figure 9 confirms the unremitting growth of the truck fleet since the mid-1960s, while rail's fleet peaked in the mid-to-late 1970s. These trends should be juxtaposed against the changing structure of the economy over the past century (Figure 10). The growth in the rail fleet

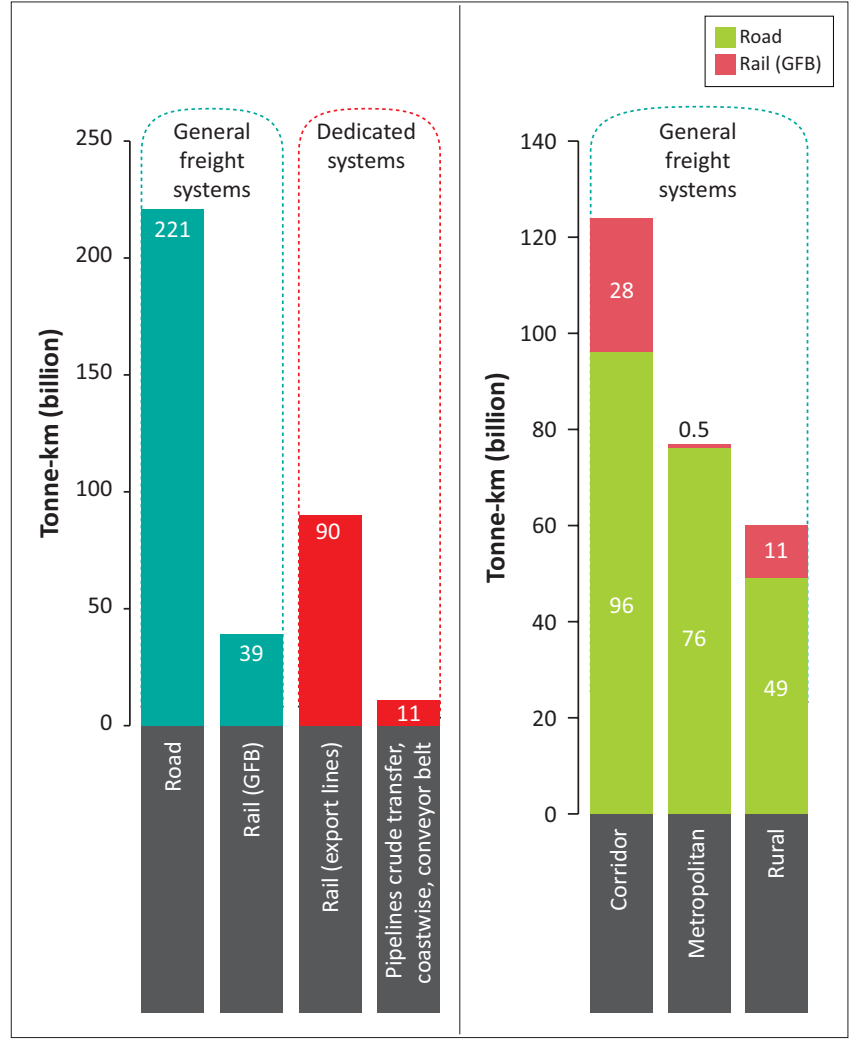

FIGURE 8: Tonne-kilometres by mode and typology (2013).

up to 1980 served the growing needs of the mining economy (a natural market for rail), while rail's tariff cross-subsidisation between primary and secondary economy traffic (in order to maintain low-density agricultural services, a government requirement) encouraged the growing truck market as manufacturers sought a better service-tariff relationship. Rail did not invest in new services and technologies to serve 


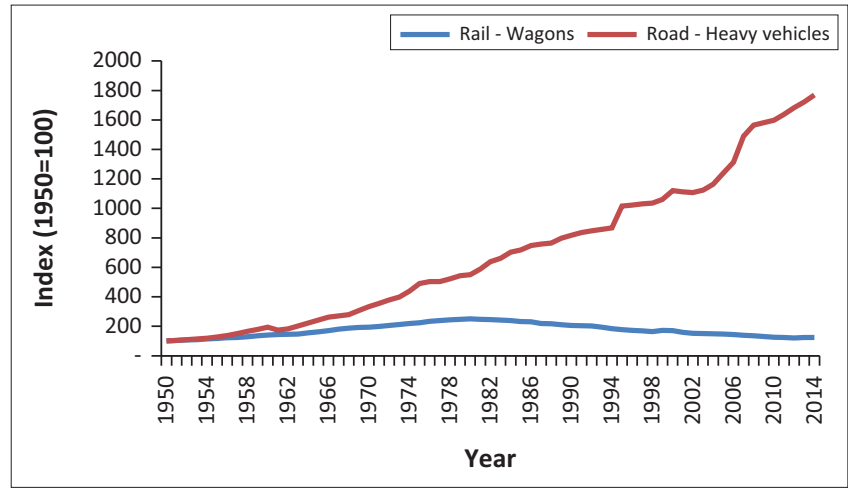

Source: eNatis (Electronic national administration traffic information system), 2015, Statistics Live vehicle population, viewed 09 September 2015, from http://www.enatis.com/index. php/statistics/13-live-vehicle-population and Transnet Freight Rail, 2015, Unpublished fleet data, Transnet, Johannesburg

FIGURE 9: South African growth in heavy vehicle population (eNatis 2015) compared with rail wagons (Transnet Freight Rail 2015).

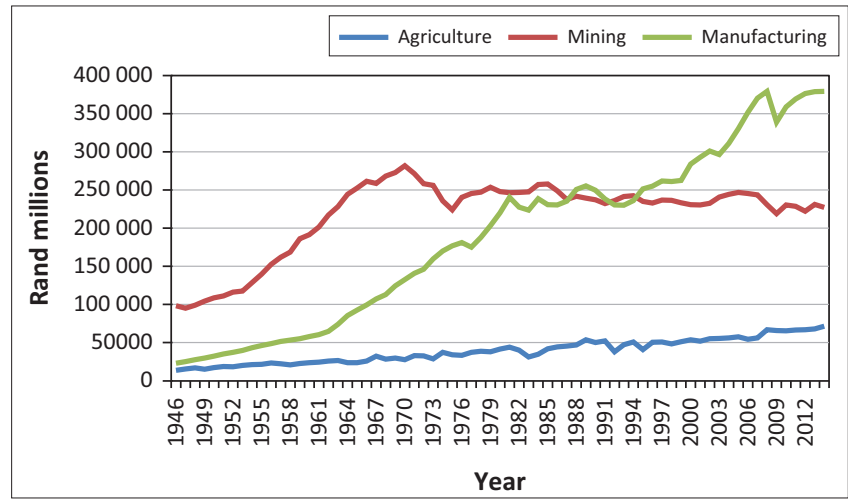

Source: Constant 2010 prices South African Reserve Bank, 2015, Online statistical query: KBP6631, KBP6632, KBP6634, viewed 05 September 2015, from https://www.resbank.co.za/ Research/Statistics/Pages/OnlineDownloadFacility.aspx

FIGURE 10: South African gross domestic product - primary and secondary sectors (constant 2010 prices).

the manufacturing economy (refer to Literature review and Havenga, Simpson \& De Bod 2014).

The freight modelling forecast indicates that, in 30 years, the freight task is expected to grow to 1981.4 million tonnes, that is, a $160 \%$ or a 2.5 -fold increase (Transnet 2015). Significant investment plans are on the cards to address crucial capacity shortages on national road corridors, port and rail infrastructure (Doke 2015). While some progress has been made with regard to the development of intermodal solutions on the long-distance corridors, with Transnet and major 3PLs entering into memoranda of understanding (Railways Africa 2013; Sanews 2014) and pilot projects, more urgency is required to make this a reality for South Africa.

\section{Conclusion}

Logistics is a strategic resource for the South African economy and key to providing a global competitive advantage. The Logistics Barometer depicts the end results of logistics decision-making. Currently, the results point to a disproportionate transport demand compared with the size of the economy, a low rail long-distance market share and high logistics costs compared with developed countries. South Africa's freight flow forecast, which has been calibrated over the past decade with industry experts and through hind-casting, provides a very good indication of economic demand based on the current trajectory. Providing the freight logistics services to meet this demand will be at best challenging. The implementation of domestic intermodal solutions is an overdue intervention to facilitate the relative uncoupling of transport demand and GDP. Other transport supply-side efficiency measures, such as more fuel-efficient vehicles, need to continue supporting this. The next step is the development of a macroeconomic understanding of final demand reduction possibilities, such as spatial reorganisation and localisation, in an attempt to lessen the load on transport infrastructure and facilitate the absolute uncoupling of transport demand and GDP.

\section{Acknowledgements Competing interests}

The authors declare that they have no financial or personal relationships which may have inappropriately influenced them in writing this article.

\section{Authors' contributions}

J.H.H. was responsible for the writing and analysis, and A.d.B. was responsible for the project management. Z.P.S. was responsible for the analysis and modelling, N.V. was responsible for the scientific editing and writing, whereas D.K. was responsible for the scientific editing and analysis.

\section{References}

Armstrong \& Associates Inc., 2015, Global 3PL Market Estimates, viewed 15 August 2015, from https://www.3plogistics.com/3PLmarketGlobal.htm

Association of American Railroads, 2013, We invest so America moves: How railroads spend their money, viewed 10 September 2015, from http://archive. freightrailworks.org/spending/

Association of American Railroads, 2015a, Impact of the Staggers Rail Act of 1980, viewed 10 September 2015, from https://www.aar.org/BackgroundPapers/ Impact $\% 20$ of $\% 20$ the $\% 20$ Staggers $\% 20$ Act.pdf

Association of American Railroads, 2015b, Rail Intermodal Kkeeps America Mmoving viewed 10 September 2015, from https://www.aar.org/BackgroundPapers/ Rail\%20Intermodal.pdf

Australian Government, 2013, Statistical report - Yearbook 2013, Australian Infrastructure Statistics, Department of Infrastructure and Regional Development Bureau of Infrastructure, Transport and Regional Economics, viewed 12 Augus 2015, from https://bitre.gov.au/publications/2013/files/INFRA1886 R BITRE INFRASTRUCTURE_YEARBOOK_0813_web.pdf

Browne, M., Woodburn, A. \& Allen, J., 2007, 'Evaluating the potential for urban consolidation centres', European Transport 35, 46-63.

CSIR, Imperial Logistics \& Stellenbosch University, 2013, Bold steps forward. 10th Annual State of Logistics Survey for South Africa, viewed 1 September 2015, from http://www.csir.co.za/sol/

Doke, L, 2015, 'Investment still needed in transport infrastructure', Mail and Guardian, viewed 17 July, from http://mg.co.za/article/2015-07-17-investmentstill-needed-in-transport-infrastructure

eNatis (Electronic national administration traffic information system), 2015, Statistics - Live vehicle population, viewed 09 September 2015, from http://www.enatis. com/index.php/statistics/13-live-vehicle-population

Eurostat, 2014, Freight transport statistics, viewed 15 August 2015, from http://ec europa.eu/eurostat/statistics-explained/index.php/Freight_transport_statistics

Ghaderi, H., Fei, J. \& Cahoon, S., 2015, 'The impediments to the competitiveness of the rail industry in Australia', Asia Pacific Journal of Marketing and Logistics 27(1) 127-145. http://dx.doi.org/10.1108/APJML-11-2013-0136

Hatch, A.B., 2014, Ten years after: The second intermodal revolution, viewed 08 September 2015, from http://www.intermodal.org/information/research/assets/ tenyrsafter.pdf

Haucap, J. \& Pagel, B., 2014, Development of rail freight in Europe: What regulation can and cannot do, Centre on Regulation in Europe, viewed 06 September 2015, from http://www.cerre.eu/sites/cerre/files/141211_CERRE_RailFreight_DE_Case_ Study_Final.pdf 
Havenga, J.H., 2010, 'Logistics costs in South Africa - The case for macroeconomic measurement', South African Journal of Economics 78(4), 460-478. http://dx.doi. org/10.1111/j.1813-6982.2010.01252.x

Havenga, J.H., 2012, 'Rail renaissance based on strategic market segmentation principles', Southern African Business Review 16(1), 1-21.

Havenga, J.H., 2013, 'The importance of disaggregated freight flow forecasts to inform transport infrastructure investments', Journal of Transport and Supply Chain Management 7(1), 1-7. http://dx.doi.org/10.4102/jtscm.v7i1.106

Havenga, J.H., 2015, 'Macro-logistics and externality cost trends in South Africa underscoring the sustainability imperative', International Journal of Logistics Research and Applications 18(2), 118-139, viewed n.d., from http://www. tandfonline.com/doi/abs/10.1080/13675567.2015.1015509?journalCode=cjol20

Havenga, J.H. \& Pienaar, W.J., 2012, 'The creation and application of a national freight flow model for South Africa', Journal of the South African Institution of Civil flow model for South A
Engineering 54(1), 2-13.

Havenga, J.H. \& Simpson, Z.P., 2012, 'National logistics costs and global trends', 9th Annual State of Logistics Survey for South Africa, CSIR, Imperial Logistics and Stellenbosch University, viewed 10 September 2015, from http://www.csir. co.za/sol

Havenga, J.H. \& Simpson, Z.P., 2013, 'Logistics cost and efficiency', 10th Annual State of Logistics Survey for South Africa, CSIR, Imperial Logistics and Stellenbosch University, viewed 10 September 2015, from www.csir.co.za/sol

Havenga, J.H., Simpson, Z.P. \& De Bod, A., 2014, 'South Africa's freight rail reform A demand-driven perspective', Journal of Transport and Supply Chain Management 8(1), 1-7. http://dx.doi.org/10.4102/jtscm.v8i1.153

Havenga J.H., Simpson Z.P., De Bod, A. \& Pienaar, W.J., 2013, 'Rail benchmarking New paradigms: A South African position', Corporate Ownership \& Control 11(1), 233-242.

Nelldal, L. \& Troche, G., 2000, 'How the railways should solve Europe's freight transportation headaches', Proceedings of Seminar $\mathrm{H}$ of the European Transport
Conference 2000, Developing Rail Policy for People and Freight, Cambridge, UK, Conference 2000, Developing
11-13 September, pp. 83-104.

Railways Africa, 2013, 'Barlowworld Logistics \& Tfr Sign Mou', viewed 10 September 2015, from http://www.railwaysafrica.com/news/barlowworld-logistics-tfr-sign-mou

Sanews, 2014, 'Transnet signs memorandum with Imperial Logistics', viewed 10 September 2015, from, http://www.sanews.gov.za/south-africa/transnet-signsmemorandum-imperial-logistics
SAPIA, 2015, Industry overview - Fuel prices archive, viewed 10 September 2015, from http://www.sapia.co.za/industry-overview/old_price.html

South African Reserve Bank, 2015, Online statistical query: KBP6631, KBP6632, KBP6634, viewed 05 September 2015, from https://www.resbank.co.za/ Research/Statistics/Pages/OnlineDownloadFacility.aspx

Stellenbosch University, 2015, Logistics Barometer South Africa 2015, viewed 10 September 2015, from http://www.sun.ac.za/logisticsbarometer

Tomlinson, J., 2009, History and impact of the intermodal shipping container, Pratt Institute, viewed 10 September 2015, from http://www.johntomlinson.com/ docs/history_and_impact_of_shipping_container.pdf

Transnet, 2015, 'Freight and energy demand forecast', viewed 10 September 2015 from http://www.transnet.net/BusinessWithUs/LTPF\%202015/2_LTPF\%202015 FDF_24\%20Aug_LR.pdf

Transnet Freight Rail, 2015, Unpublished fleet data, Transnet, Johannesburg.

Transportation Research Board, 2011, Performance measures for freight transportation, National Cooperative Freight Research Program Report 10, viewed 03 September 2015, from http://onlinepubs.trb.org/onlinepubs/ncfrp/ncfrp_ rpt_010.pdf

United States Department of Transportation, 2015, Table 1-50 - U.S. Ton-Miles of Freight (BTS Special Tabulation), National Transportation Statistics, viewed 26 November 2015, from http://www.rita.dot.gov/bts/sites/rita.dot.gov.bts/ files/publications/national_transportation_statistics/index.html

Verny, J., 2007, 'The importance of decoupling between freight transport and economic growth', European Journal of Transport and Infrastructure Research 7(2), 113-128

Woodburn, A., 2012, 'Intermodal rail freight activity in Britain: Where has the growth come from?', Research in Transportation Business \& Management 5, 16-26. http://dx.doi.org/10.1016/j.rtbm.2012.09.001

World Bank, 2012, 'Decoding sustainable logistics trends: Viewpoints from leading practitioners', viewed 03 September 2015, from http://web.worldbank.org/ WBSITE/EXTERNAL/TOPICS/EXTHEALTHNUTRITIONANDPOPULATION/EXTPRH/0, contentMDK:23204105 menuPK:376899 pagePK:64020865 piPK:51164185 th eSitePK:376855,00.html

World Bank, 2015, 'Economy and growth', viewed 03 September 2015, from http:// data.worldbank.org/topic/economy-and-growth 